\title{
Ya Gotta Keep Your Head Up: Rebuilding Self-Confidence and Self-Worth in Prison with Rock-Bottom Resiliency Emily O'Brien
}

B eing referred to as a 'mule' is not the most endearing of titles to have of the horse family, the offspring of a male donkey and a female horse; the farm animal that no one really cares for. In the drug trafficking world, mules are persons acting as a courier for illicit drugs. For years and years, the higher ups in drug organizations have been recruiting women of all socioeconomic backgrounds to transport drugs (Campbell, 2008). Some of these women enter the trade willingly and others not so willingly (ibid). Either way, because they are viewed as disposable, many will be "sacrificed" at the border to get larger amounts of narcotics through. They are simply used as a distraction and are forgotten as soon as they are arrested.

I quickly learned that I was that disposable distraction, and at first, this made me feel like garbage. I already felt like garbage because I knew I was breaking the law, and my body was showing physiological signs of discomfort and distress, but I kept my silence because I was wary of the possible repercussions. It seemed everyone was in on it, so I thought that if I went to anybody they would find out and do God knows what to me. These people are, what I like to call, the professional "petrifiers". You are so unfamiliar with a world that you believe anything. After you get back, you realize that instilling fear is really all they usually do because it could easily be determined whom you travelled with and where you were, and if I was to disappear, it would prompt an international investigation and media frenzy. I speak as a Canadian coming from a middle-class family, so I know this is not necessarily true for women in other countries. That being said, I decided I was not going to take any chances and was groomed to the extent that I was led to believe nothing could possibly go wrong. I felt so pathetic after realizing how incredibly ignorant I was. In a way that very few of the other prisoners could comprehend, I was relieved when I got caught; being disposable felt okay because I wanted them to forget about me. I wanted to disappear.

After the arrest, I felt so ashamed, confused and incredibly uneasy. My parents had to bail me out and I could barely look at them. They were just as confused as I was, but thankful I was okay. I know they were disappointed, and it took me awhile to make them believe that I had never done this 
before. This was the truth. I had no idea the size of the legal mountain my family and I were all going to have to climb over the next few years. The magnitude of the situation was surreal. I had to move back home with my mom, which was infantilizing enough, and I also had to comply with strict regulations for the duration of the court case. I felt incredible guilt every day and constantly saw the horrific stress the whole situation was placing on my family. They tried to brush it off sometimes, but I knew that until this was over, tension would always be lingering. I was used to being completely independent and now was completely dependent. Life was not supposed to happen that way. We are supposed to be dependent on others when we are children, and again dependent on others when we are old and ailing. I wanted them to be dependent on me, but here I was, at 27 , relying on my parents. Again. When I knew damn well I could look after myself, the legal system thought I could not possibly contribute any good to the world so kept my whereabouts incredibly limited. This frustrated me so much to the extent that I would go to the gym and just punch the punching bag till my knuckles were bruised and bleeding. I had now acquired my second tarnishing title: criminal.

\section{REBUILDING SELF-WORTH}

For two and a half years, I did not go on like normal. I did not just quit life, in fact, I did the opposite. I propelled myself to work harder than I ever had before. I went to networking events and conferences constantly, and when I had to shut down my business because it was time to serve my sentence, I had to refer just under 80 clients to my competitors!

I refused to accept that I was a criminal. I knew I had broken the law, but I also knew that other than this arrest, I spent my time helping others build their businesses and also spent time giving back. I believed myself to be good natured person, always willing to give a helping hand whenever I had the chance. I was determined to uphold this part of myself, which is why I spent my time on bail always working. I thrived off knowing that people went to me to help their business succeed. I had an extensive network of friends, spanning over multiple countries, and knew that I simply would not have the friends that I did if I was the piece of shit that the police said I was. They really knew nothing about my life. They only knew about my life that day. One day out of one year out of the $27 \mathrm{I}$ had lived so far up to that point. 
Once you get to prison all other identities are stripped away from you and you are told what to do on a daily basis. You have very few of your belongings, you do not have your family and you most certainly do not have privacy. I knew I had to roll with the punches and I was ready. I would not let prison destroy me, I just would not. I knew that what I had done was wrong and was anxious to focus on centering in on what I could have done differently. I had so many questions that I needed answers for so that when I got out, I could offer the solutions I learned before and just perhaps, could prevent someone from facing the same fate I did. Finding confidence and rediscovering your self-worth is not easy and it takes consistent effort, but it is possible. I thought I would share some of the ways I cultivated the strength to ditch feelings of worthlessness and adopt the assurance that I would again do meaningful, positive things for the rest of my life.

1. Let go of trying to fix out of reach problems: If you keep trying to fix things that cannot be fixed or try to control things that are out of your control, you are always going to be frustrated and feel like a failure. Work with things within your reach.

2. Learn by reading: The more you read, the more you know. The more you know, the more confident you will be. Pick a subject that interests you and get library books on it. Ask relatives over the phone for book titles related to that subject so you can request them out of the library. There is so much free and valuable information out there, so take advantage of it.

3. Write to someone that inspires you: Make it authentic and real, and they will more than likely write you back. Handwritten letters are personal and they are way more likely to be opened than an e-mail (because everyone emails these days). I wrote a letter to Lawrence Hill, author of The Book of Negroes, telling him how his book helped me learn so much from a historical point of view and that it gave me a refreshing, more informed perspective. He wrote me back thanking me, encouraged me to write a memoir of my own, and offered to meet up with me when I was released.

4. Help other prisoners: We are all in this together, and if you can contribute by adding value to someone else's experience, do it. They will be forever grateful and you will feel appreciated. Little things go a long way. 
5. Stay sober: I cannot express how being sober has improved my overall mental health. People use substances to avoid pain, but when the substances are gone, you feel even worse due to the chemical imbalances in your brain. Of course, everyone is going to have bad days, but they are not nearly as dark as the ones following substance abuse.

6. Set and stick to your boundaries: You simply cannot solve other people's problems. Do not let people try to pressure you into thinking you are responsible for their happiness. It is nice to be a good listener, but not having "you" time inhibits your ability of making your own progress. This is your time, no one else's.

7. Reach out for support: Write to a family member you have not spoken to in a while or an old friend you lost contact with. You will be surprised how many people will be understanding and want to hear your side. Getting letter mail in return is really rewarding, especially when you feel forgotten.

Sometimes life kicks the shit out of you and it sucks. There are very few days that go by that go exactly as planned. Disorder seems as though it is the new order. As we get older, we begin to realize that the picture-perfect life plan we wanted to live has veered so far off course we do not even know if we are living on this planet anymore. Not only do we need a plan B, but we need to keep plan C, D, E, F within arm's reach, next to your pack of cigarettes and bottle of vodka. As I shared above, I can certainly say that prison was never part of my life plan. It goes without saying that I do not think it is part of anyone's life plan. Even the people I have met who were heavily involved in organized crime seemed to operate as if they would never be caught. In my case, I initially did not think prison was even an option. I knew I was tough, but jail tough? I was not so sure. Until I was.

\section{ROCK-BOTTOM RESILIENCY: SPRINGING FORWARD FROM THE GROUND UP}

Resiliency is the buzzword and mandatory transferable skill that necessitates the survival of modern-day life. It is routinely defined as the ability to navigate through a variety of the uttermost difficult yet common narratives 
such as sudden deaths, births, job loss, and sickness (Southwick et al., 2014). Unfortunately, resiliency does not come naturally. We are not born with it, rather it is something we develop through happening. No one, unless you are a complete psychopath, can experience something as life-altering as prison for the first time (or any-time for that matter) and pretend as if nothing ever happened. In reality, the more adversity we experience, the more resilient we can become. Every time we face a new type of zero, we build a new type of resilience. However, the basic building blocks for engineering resiliency are universal and can be applied to any situation. I have already touched on mindset and confidence above, the former being a component of resilience and the latter being a product of it. If there is one quality of character which will drive you towards the type of success that I describe above, it would be resiliency. This is why I will conclude with some thoughts on how one can build this overarching, multi-faceted quality that makes everything more manageable and can serve as a catalyst for long-term growth.

In January 2018, the legal system had just beat me to a pulp and it did not feel good. I knew I was mentally, physically, emotionally and financially weak. I had finally accepted I was going to prison. My legal fees were so expensive and had pulled me into debt. Initially, I was fantastically enraged that I had to pay 50k and still had to go to prison, until I realized my lawyer had actually done a good job. I also had to shut my business down. My family also had to pick up some of my financial commitments for the time being. Luckily, I had some outstanding invoices owed to me that I was able to collect so I could make my car payments. My alcohol and drug abuse had wreaked havoc on my emotional stability and I knew it. I also knew that the next 10 or so months were going to be tough, but I knew that I would figure out a way to not just survive, but thrive in prison. I also knew that by facing this challenge head on, I would be able to catch anything else life threw at me and turn it into gold.

Resiliency can be cultivated in a variety of ways. It must be noted that resiliency is not burying a problem, which is what a lot of people do. This may work in the short-term, but for us to overcome our challenges, we need to face them head on or they will haunt us for the rest of our lives. Some folks have simply not learned how to be resilient at all and, unfortunately, they often give up. Facing my prison sentence, I decided that I would take a different route. My pathway to picking myself up went as follows. 
1. Accept that you will be giving up control to the rule of law: The judge made the decision and I knew I would not have my liberty until I had paid my dues. Okay, so things do not seem fair. So what? I sucked it up. So much wasted energy goes into things that are uncontrollable. Since coming to prison, I have gotten to know so many kind and nurturing women here. The next challenge then, is helping everyone rebuild the self-confidence they once had and restoring their self-worth to make them want to live healthy, happy, law abiding, and meaningful lives upon release. I knew I was going to prison for 10 months, so I had to focus on what results I could produce within that time.

2. Have an optimistic outlook: This is a given. I chose to view my sentence as a time to detox, write and read, while planning my next business. I could have nit-picked every little thing, but I chose not to because it puts you in a negative mood. Find the good in everything, period. When you display a good attitude, people will catch on. The same goes for a negative attitude. Emotions are contagious. Make your surroundings more uplifting by being uplifting. Never stop being grateful, even if it is for something simple as clean water.

3. Reframe perceived liabilities into assets: I knew I would find something redeeming about coming to prison. Highlight all the skills you have worked at the various jobs. Plan to tell future employers the truth. They will admire the honesty and authenticity, and respect the fact that you admitted to doing something wrong. Those are all desirable qualities any employer would want in an employee. I did it once before when I told an employer I had a DUI. He hired me on the spot.

4. Abandon grudges, they are exhausting: It is possible that you will not get along with everyone, but every minute you spent gossiping and thinking about how much you hate someone else, is one less minute you spend on working on yourself. The less time you spend working on yourself, the less you grow.

5. Build healthy and solid networks: Believe it or not, but there are tons of different communities even in prison. There are cultural groups, religious groups, fitness groups, recovery groups, etc. There are also the not 
so good ones-these will end up crippling you. Do not worry about fitting in with everyone, because you will not. Shared experiences create strong experiences. I worked with the volunteers that come in. They wanted to help. They would not have spent 12 hours filling out the volunteer-application and doing the rigorous training if they did not. They will want to help connect you to other positive people because they want to see you do well.

6. Read up! Two of the best books I have read so far are: Resiliency by Lisa Lisson (President of Fedex Canada) and Type R: Cultivating Resiliency in a Turbulent World by Amy Marston. It is so helpful to see how everyone has different yet equally powerful ways of finding strength when they are at their lowest. Another option other than utilizing the library is getting friends on the outside to print you off articles and mail them in, so you can read them whenever you want.

7. Be patient: You will not learn the lessons you are supposed to learn after one day. You will not recover from a loss after one day. You need to give these things months, even years so that you will be able to see the meaning in the best light.

Do things that are out of your comfort zone. This does not come naturally to all people. Try to monitor what you do on a daily basis. After every activity, try to see what you learned. These can range from tangible skills to transferable ones. Even if you really despise doing something (I could not stand being a house rep at first because I felt out of control), try to work on it. Often the things you hate doing the most are the places where you see the most growth. Did I think being a house rep was helping me? No. In all honesty, it was driving me batty. But then I realized very few people can say they had the leadership experience that I did, which continues to serve me today despite the many challenges that come with federal imprisonment.

\section{REFERENCES}

Campbell, Howard (2018) "Female Drug Smugglers on the US-Mexico Border: Gender, Crime, Empowerment", Anthropological Quarterly, 81(1): 233-267.

Southwick, Steven George Bonanno, Ann Masten, Catherine Panter-Brick and Rachel Yehuda (2014) "Resilience Definitions, Theory, and Challenges: Interdisciplinary Perspectives", European Journal of Psychotraumatology, 5(1): 1-14. 


\begin{abstract}
ABOUT THE AUTHOR
Emily O'Brien, social entrepreneur and prison advocate, started Cons and Kernels popcorn company inside Grand Valley Institution for Women. She also works with employers to help them create more inclusive hiring policies to create opportunities for the formerly incarcerated.
\end{abstract}

